\title{
Combination of mild heat and calcium chloride treatment on the texture and bioactive compounds of purple shallot
}

\author{
*Thuy, N.M., Tuyen, N.T.M. and Tai, N.V. \\ Department of Food Technology, College of Agriculture, Can Tho University, 900000, Can Tho, Vietnam
}

\author{
Article history: \\ Received: 24 May 2020 \\ Received in revised form: 12 \\ June 2020 \\ Accepted: 13 June 2020 \\ Available Online: 16 June \\ 2020
}

Keywords:

Mild heat temperature,

Calcium chloride,

Texture,

Purple shallot,

Bioactive compounds

DOI:

https://doi.org/10.26656/fr.2017.4(5).245

\begin{abstract}
Purple shallot (Allium ascalonicum L.) is one of the most tropical agricultural crop widely used as a food seasoning. It is a highly commercial and important commodity by the food industry, not only based on its economic value but also the bioactive compounds. Pretreatment is widely used before processing of agro-products to improve the quality of these products. In this study, the influences of the pretreatment were conducted by the combination of mild temperature ranging from 45 to $55^{\circ} \mathrm{C}$ and different concentrations of calcium chloride (from 0.25 to $0.75 \%$ ) on the quality of raw purple shallot used for further study (e.g. freeze-drying and pickling). The samples were analyzed for the firmness, bioactive compounds (total phenolic, total flavonoid and quercetin content) and antioxidant activity. The results showed that mild water temperature and calcium chloride concentration were influent on the firmness and bioactive compounds of raw material. The addition of calcium can enhance the beneficial action of mild heat treatments on sensory properties of purple shallot. The optimal conditions of the process were stabilized with the desired function, obtained at $50^{\circ} \mathrm{C}$ of mild hot water temperature dipping and $0.64 \%$ of calcium chloride concentration.
\end{abstract}

\section{Introduction}

In the Mekong Delta of Vietnam, Soc Trang province possesses the largest purple shallot cultivation area, most of which is in Vinh Chau town. Purple shallot is also an important vegetable crop in Vietnam and throughout the world, which has produced high annual productivity for its daily uses and economic benefits. It is becoming the sources of livelihood for many peoples who have engaged in production. Purple shallot is an outstanding source of polyphenols, including the flavonoid polyphenols and quercetin (Thuy et al., 2020). Consumption is believed to benefit health due to their bioactive compounds have potential anti-inflammatory, anti-cholesterol, anticancer and antioxidant properties (Hashmi et al., 2015). The physico-chemical characteristics of purple shallot are important similar to aromatic properties. Therefore, physico-chemical parameters perception is an important factor for quality evaluation of purple shallot and critical in determining the usability for further processing. The pretreatment before vegetable processing can improve the quality of the final product, prevent browning and help retain volatile compounds. Various methods of pretreatment have been applied such as chemical pretreatment or blanching. Heat treatment has been shown to successfully improve the quality and shelf life of freshcut products and retain texture (Gómez-López, 2012). Mild heat treatments, however, do not use harsh chemicals, are environmentally friendly. Heat treatment could protect the ultra-structure of the pericarp cells in the heat pre-treated dragon fruit under chilling stress (Lum and Norazira, 2011). Chemical pretreatments such as calcium chloride dipping can increase the drying rate by removing the surface resistance of fruits or vegetables and retain firmness (Tunde-Akintunde, 2010). The addition of calcium can enhance the beneficial action of mild heat treatments on sensory properties of processed fruit and vegetables (Gómez-López, 2012). Numerous studies have been carried out for optimizing the operational parameters and design of blanching processes for different vegetables and fruits. The effects of the combination of mild heat and calcium treatment on vegetable quality have been studied (Lamikanra, 2001; Gómez-López, 2012), but most of the consulted literature about shallot is still limited with insufficient data. This study describes a study of the combination of mild heat and calcium chloride pretreatment on the quality of material used for heat/non heat - processing (such as pickling and drying) in the next study. 


\section{Materials and methods}

\subsection{Sample collection and preparation}

The freshly and matured purple shallot were harvested from Vinh Chau town, Soc Trang province, Vietnam. The shallot bulbs usually take around 60-65 days to mature. After harvesting, the bulbs are dried out some in the garden for about a week and then store them in mesh bags in a cool and dry location. In each experiment, the outer skin of shallot bulbs was removed by stainless steel knife. The peeled purple shallot bulbs were thoroughly washed under tap water to remove foreign matters. The drying may take place in one hour of air drying $\left(55-60^{\circ} \mathrm{C}\right)$ to remove the surface water. The experiment mainly consists of the preparation of the chemical solution and the combination of mild heat and chemical treatments.

\subsection{Effect of pretreatments on quality of purple shallot}

\subsubsection{Preparation of chemical solution}

The chemical pretreatment on purple shallot was carried out with calcium chloride $\left(\mathrm{CaCl}_{2}\right)$ in distilled water on a percentage basis $(0.25,0.50$ and $0.75 \%)$.

\subsubsection{Mild heat and chemical combination pretreatment}

The effect of the combination of thermal and chemical pretreatments to purple shallot halves using calcium chloride $\left(\mathrm{CaCl}_{2}\right)$ was examined by dipping $500 \mathrm{~g}$ of prepared sample in the respective prepared chemical solution (as mentioned above) at different temperatures $\left(45,50,55^{\circ} \mathrm{C}\right)$ in the water bath for 10 mins as suggested by Thuy et al. (2013). After blanching, the samples were cooled in cold water and removed the excess water with tissue paper before drying. The hardness, bioactive compounds and antioxidant activity of purple shallot were analysis in triplicate.

\subsection{The quality analysis}

Hardness testing: Texture attributes were analyzed with a Brookfield CT3 Texture Analyzer equipped with a 1,500 g load cell and software version 1.8 (Brookfield Engineering Laboratories, Middleboro, MA, USA) using the following settings: text type: TPA (texture profile analysis); test speed: 2 mm/g; target type: Stop @ Load; target value: $1000 \mathrm{~g}$ and trigger force: $5 \mathrm{~g}$. Five randomly samples were placed perpendicular to the long edge of the probe on the fixture base table. A wedgeshaped probe (part number TA-PFS) was used for texture profile analysis.

\subsection{Bioactive compound analysis}

\subsubsection{Preparation of purple shallot extracts}

The ground samples were extracted using pure methanol for $1 \mathrm{hr}$ at $40^{\circ} \mathrm{C}$ using a water bath shaker (Daihan, China) (Kosar et al., 2007). The residues, separated by filtering through Whatman filter paper, were re-extracted twice with the fresh solvent. The three extracts were pooled and then methanol was distilled off at $40^{\circ} \mathrm{C}$ using a rotary vacuum evaporator (Büchi, Switzerland). The resulting crude concentrated extracts were used for the analysis of chemical compounds and antioxidant activity

\subsubsection{Determination of bioactive compounds and antioxidant activity}

The total phenolic compounds (TPC) were determined using a modified Folin-Ciocalteau colourimetric method (Wolfe et al., 2003). The content of total phenolic compounds was expressed as $\mathrm{mg}$ of gallic acid equivalents per $\mathrm{g}(\mathrm{mg} \mathrm{GAE} / \mathrm{g})$.

Determination of total flavonoid content (TFC) was performed using the $\mathrm{AlCl}_{3}$ colourimetric method (Chang et al., 2002). Quercetin was used to develop a standard calibration curve and the TFC was expressed as milligrams of quercetin equivalents per gram $(\mathrm{mg} \mathrm{QE} / \mathrm{g})$.

Quercetin content was determined by positive mode of LC-ESI-QQQ (6460 Triple Quadrupole System, Agilent, USA) coupled with a UV detector (1260 Infinity, Agilent, USA). The UV detection wavelength was set at $370 \mathrm{~nm}$ (the maximum absorption wavelength of quercetin) (Thuy et al., 2020).

The DPPH scavenging activity (DPPH\%) assay for the purple shallot extracts was performed using the method described by Liyana and Shahidi (2005) with a slight modification.

\subsection{Statistical analysis}

Statistical analysis was conducted for all of the above determinations using a statistical program (ANOVA), such as the multiple range tests and multiple regression analysis. Pre-treatment parameters were analysed by using the multiple regression analysis. A statistical analysis (STATGRAPHICS) was used to fit the model to the observed data. The proposed model (equation 1) for each response (Y) was:

$Y=b_{o}+\sum_{n=1}^{3} b_{n} X_{n}+\sum_{n=1}^{3} b_{n n} X_{n}^{2}+\sum_{n \neq m=1}^{3} b_{n m} X_{n} X_{m}$

Where: $b_{o}$ is $Y$-intercept (constant), $b_{n}$ is regression coefficient for the linear effect of $X_{n}$ on $Y, b_{n n}$ and $b_{n m}$ are regression coefficients for quadratic effect on $Y, X_{n}$ and $X_{m}$ are independent values.

In the multiple regression analysis, the physical characteristics (hardness), bioactive compounds (TPC, TFC, QE) and antioxidant activity (DPPH\%) were 
defined as the dependent variables and the $\mathrm{CaCl}_{2}$ concentration, treatment temperature which were presented in $\mathrm{X}$ and $\mathrm{Y}$ values were defined as independent variables. The reference equation was selected to fit the data, based on the $\mathrm{R}^{2}$ value obtained from the multiple regression. The selected reference equation should have a higher $\mathrm{R}^{2}$ value.

\section{Results and discussion}

3.1 Effect of combination of mild heat and $\mathrm{CaCl}_{2}$ on the hardness of purple shallot

Calcium contributes to improving the stiffness of cell walls and also reduces the activity of the pectinase enzyme, which is a major cause of cell degeneration (Vicente et al., 2009). The hardness of the purple shallot increased noticeably $(+8.07 \%)$ when the concentration of $\mathrm{CaCl}_{2}$ increases from 0.25 to $0.5 \%$ (Figure 1). At higher concentrations $(0.75 \%)$, the sample hardness does not increase. $\mathrm{CaCl}_{2}$ which is used more when the objective is the preservation and/or the enhancement of the product firmness (Alzamora et al., 2005; Manganaris et al., 2007). The concentrations of the calcium salts used as dipping treatments in this study within a range of 0.25 to $0.75 \%$, less than the concentration of $\mathrm{CaCl}_{2}$ that used by Luna-Guzman and Barrett (2000) with a range of 0.5$3 \%$. Applying calcium treatment may contribute to cell wall integrity by increasing the amount of endogenous calcium available to bind with de-esterified pectic residues. Not only preserving firmness, but post-harvest calcium dips also reduce respiration, decrease ethylene production and delay senescence in fresh tomatoes (Artes et al., 1999).

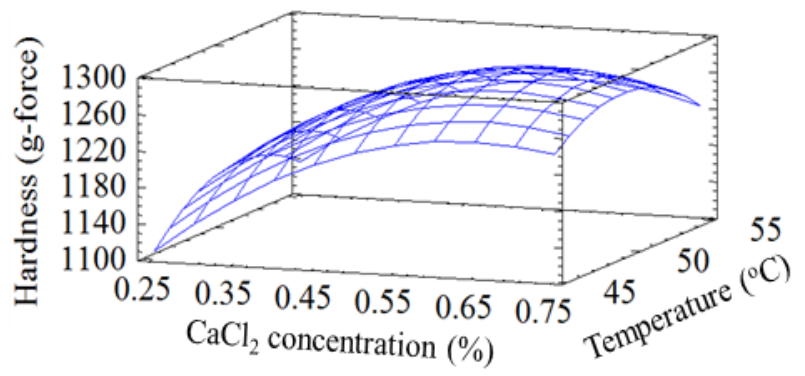

Figure 1. Influence of calcium concentration and treatment temperature on the hardness of purple shallot

The concentration of the calcium dip depends on the vegetable being treated and many studies report that $1-$ $2 \%$ calcium salts are most effective for diced tomatoes (Castaldo et al., 1996), cantaloupes (Luna-Guzman and Barrett, 2000) and pears (Dong et al., 2000). Calcium salts also reduce the adverse effects of temperature on the structure of heat treatment products (Suutarinen et al., 2000). Previous research results also confirmed the positive effect of heat pretreatment on the improvement of vegetable structure thanks to the activity of pectin methylesterase (PME) at a temperature of $50-70^{\circ} \mathrm{C}$.
Released pectins are characterized by a high degree of methylation, which may be modified by the activity of pectin methylesterases by heat. Some regions of pectin are involved in the formation of calcium ions-pectin cross-links which help the cell walls become stronger (Sila et al., 2009; Voragen et al., 2009). Regarding temperatures, it was observed that the hardness of the purple shallot increased (about 7.93\%) when it was treated by $\mathrm{CaCl}_{2}$ in combination with the mild temperature of $45-50^{\circ} \mathrm{C}$. In previous studies, treating fruits and vegetables at the temperature of $50^{\circ} \mathrm{C}$ gave good results about the sensory value and physical properties of the products. The combination of calcium lactate and heat treatment at $50^{\circ} \mathrm{C}$ had shown to be more effective on the structure of minimally processed lettuce than it was treated at room temperature (Lamikanra, 2001). The structure of canned pineapples remains stable despite being pasteurized at $90^{\circ} \mathrm{C}$ for 1 minute thanks to the pretreatment process at $55^{\circ} \mathrm{C}$ by using $0.15 \%$ calcium chloride solution (Thuy and Tuyen, 2016). In particular, Luna-Guzmán et al. (1999) also showed that the brittleness of melon (Cucumis melo L. var. reticulatus) increased by $300 \%$ compared to control condition when it was soaked in $2.5 \% \mathrm{CaCl}_{2}$ solution for $1 \mathrm{~min}$. However, in this experiment, when treated at $55^{\circ} \mathrm{C}$, the shallots tended to reduce the hardness (about 5.35\%), perhaps due to the size of shallot is small, the shrinkage of the inner cells while exposure to high temperatures could lead to some cells collapsing and cell walls being broken.

Thermal treatments are also effective in improving the quality of postharvest horticultural products. A brief heat shock $\left(50^{\circ} \mathrm{C}\right.$ for 1.5 mins $)$ disrupts the woundinduced increase in the enzyme phenylalanine ammonialyase (PAL) activity, delayed and diminishing the accumulation of phenolic compounds and tissue browning (Loaiza-Velarde et al., 1997). Thermal treatment at $50^{\circ} \mathrm{C}$ probably inhibited the PAL activity, the enzyme involved in the first step of the phenylpropanoid pathway that leads to the increasing production of the major phenolics compounds that lead to browning (Pereyra et al., 2005). When mild heat treatment is applied to lettuce it can prevent browning by inhibiting the synthesis of PAL (Fallik, 2004). Carrea et al. (1982) showed that heating at $50^{\circ} \mathrm{C}$ for 5 mins will eliminate POD activity while PPO is still at $91 \%$ of its original activity. Thus, there is no significant benefit in the use of temperatures higher than $50^{\circ} \mathrm{C}$ for inactivation of these enzymes. A mild heat process is also intended to maximize the hardness, sensory and organoleptic qualities of products whose characteristics would be adversely affected by heating at a higher temperature. Mild heat treatment of several horticultural crops has been reported to improve product quality and shelf life 
(Gómez-López, 2012). Mild heat treatment also increased intensities of desirable attributes and reduced undesirable flavours (Gómez-López, 2012). The relationship between the hardness of shallot with the $\mathrm{CaCl}_{2}$ concentrations and treated temperatures was presented in the multiple regression equation. The equation of the fitted model (Equation 2) is as follows:

Hardness $(\mathrm{g}$-force $)=-3553.68+1539.96 \mathrm{X}+$ $174.80 \mathrm{Y}-875.48 \mathrm{X}^{2}-8.94 \mathrm{XY}-1.69 \mathrm{Y}^{2}$

$\mathrm{R}^{2}=81.32 \%, \mathrm{SEE}=35.29$

Where $X$ is $\mathrm{CaCl}_{2}$ concentration (\%) and $Y$ is treatment temperature $\left({ }^{\circ} \mathrm{C}\right)$

\subsection{Effect of combination of mild heat and $\mathrm{CaCl}_{2}$ on the} antioxidant compounds and antioxidant activity of purple shallot

\subsubsection{TPC and TFC}

Shallots are a good source of the phenolic compound such as polyphenol, flavonoid, quercetin (Gorinstein et al., 2009). Treating purple shallot in $\mathrm{CaCl}_{2}$ solution has a positive effect on the maintenance of antioxidant compounds. The effect of calcium treatment on TPC, TFC and QE in shallot were significantly different between the control (non-treated) and treated samples. This might be because the addition of calcium chloride to berries strengthened the cell wall, enhanced the formation of egg-box structure and minimized syneresis/ leaching of water-soluble compounds such as TPC, TFC. The TPC and TFC of purple shallot maintained at the relatively high amount $(13.99 \pm 0.02 \mathrm{mg} \mathrm{GAE} / \mathrm{g}$, $6.04 \pm 0.07 \mathrm{mg}$ QE/g, respectively) when it was dipped in $0.25-0.5 \%$ calcium chloride solution and did not show significant differences at higher $\mathrm{CaCl}_{2}$ concentrations $(0.75 \%)$ (Figure 2). Figure 2 also showed the changes of $\mathrm{TPC}$ contents after treatment at $45-55^{\circ} \mathrm{C}$.

As shown, TPC in the treated sample at $50^{\circ} \mathrm{C}$ maintained at relative high content (13.52 $\mathrm{mg} \mathrm{GAE} / \mathrm{g}$ ), whereas in the treated samples at 45 and $55^{\circ} \mathrm{C}$, TPC was only 11.73 and $11.91 \mathrm{mg} \mathrm{GAE} / \mathrm{g}$, respectively. $\mathrm{CaCl}_{2}$ helps stabilize the tissue structure of vegetables and fruits by binding with pectic acid to form the calciumpectate complex compound, preventing oxidation process (Ihl et al., 2003), so the TPC in shallot was maintained. At different treatment temperatures, the TPC

(a)

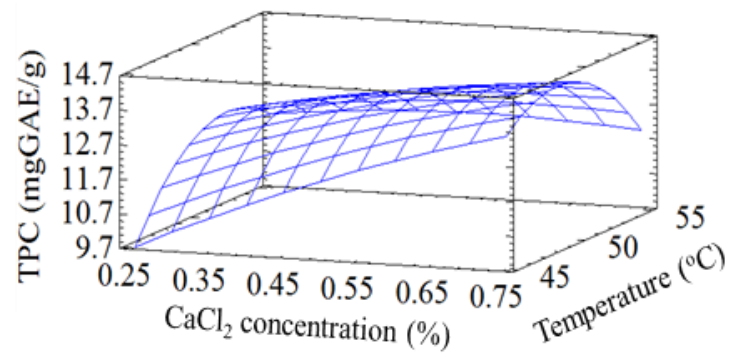

and TFC were maintained at $50^{\circ} \mathrm{C}$ but decreased at the higher temperature $\left(55^{\circ} \mathrm{C}\right)$. Gupta et al. (2011) found that in a certain range, when the temperature increases, the polyphenol content also increases; however, TPC and TFC will decrease at the temperature is too high and the time of treatment is too long. Phenolics compound often exist in soluble form and combination with plant cell walls, if vegetable tissue exposed to hot water for a long time, the heat will damage the cell wall leads to the loss phenolic compounds in products (Farsi and Lee, 2008). Reducing the activity of enzyme peroxidase (POD) and polyphenol oxidase (PPO) in samples may lead to the stable in the antioxidant compounds (Vega-Gálvezet al., 2012).

The relationship between TPC/TFC of purple shallot with $\mathrm{CaCl}_{2}$ concentration and treatment temperature was presented in the multiple regression equation. The equations of the fitted model (Equations 3 and 4) are as follows. The higher $\mathrm{R}^{2}$ values of these models indicated a good fit of the data.

$\mathrm{TPC}(\mathrm{mg} \mathrm{GAE} / \mathrm{g})=-157.61+45.61 \mathrm{X}+6.32 \mathrm{Y}-$ $4.84 \mathrm{X}^{2}-0.74 \mathrm{XY}-0.06 \mathrm{Y}^{2}$

$\mathrm{R}^{2}=90.4 \%, \mathrm{SEE}=0.49$

$\mathrm{TFC}(\mathrm{mg} \mathrm{QE} / \mathrm{g})=-50.39+18.5 \mathrm{X}+2.07 \mathrm{Y}-$

$8.83 \mathrm{X}^{2}-0.17 \mathrm{XY}-0.02 \mathrm{Y}^{2}$

$\mathrm{R}^{2}=94.14 \%, \mathrm{SEE}=0.19$

Where $X$ is $\mathrm{CaCl}_{2}$ concentration (\%) and $Y$ is treatment temperature $\left({ }^{\circ} \mathrm{C}\right)$

\subsubsection{Quercetin}

The change of quercetin content in shallot by the impact of $\mathrm{CaCl}_{2}$ during treatment shown in Figure 3. At low concentrations of $\mathrm{CaCl}_{2}(0.25 \%)$, the quercetin content was least protected, the means of quercetin content decreased slightly (about $4.08 \%$ ) after 10 mins of treatment, this result occurred due to $\mathrm{Ca}^{2+}$ ions did not form a strong bond with the cell wall. However, the higher value of quercetin was reached when the higher $\mathrm{CaCl}_{2}$ concentration was applied $(\geq 0.5 \%)$. As discussed above, the function of the $\mathrm{Ca}^{2+}$ ion is to harden the cell walls. The cell wall structure is protected by calcium pectate (Lara et al., 2004), intracellular quercetins are difficult to release outside the cell membrane. Besides,

(b)

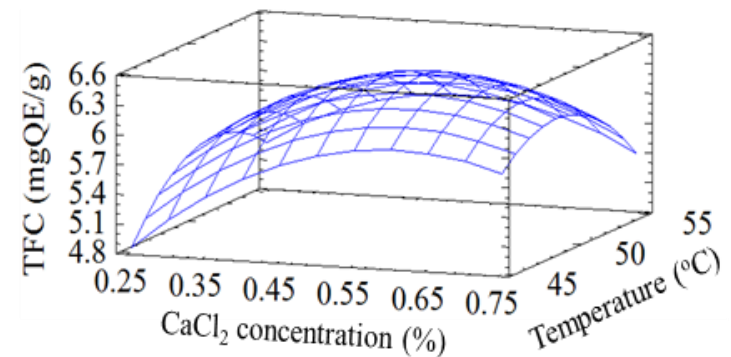

Figure 2. Influence of calcium concentration and treatment temperature on the (a) TPC and (b) TFC of purple shallot 
Rosen and Kader (1989) demonstrated the role of $\mathrm{Cl}^{-}$ ions in preventing browning, limiting the ability to decompose bioactive compounds due to oxidation. Regarding temperatures, the quercetin content in shallots was maintained better by dipping in solution at $50^{\circ} \mathrm{C}$ $(1438.02 \pm 12.94 \mu \mathrm{g} \quad \mathrm{QE} / \mathrm{g})$ whereas, at higher temperatures $\left(\geq 55^{\circ} \mathrm{C}\right)$, it could be reduced $(1403.58 \pm 35.26 \mu \mathrm{g} \mathrm{QE} / \mathrm{g})$. The quercetin and kaempferol in plant tissues were unstable due to the temperature was found by Aoyama and Yamamoto (2007). The quadratic model for $\mathrm{QE}$ of different treatment conditions is presented in equation 5 . The higher $\mathrm{R}^{2}$ values of these models indicated a good fit of the data.

$\mathrm{QE}(\mu \mathrm{g} \quad \mathrm{QE} / \mathrm{g})=-1839.86+2521.14 \mathrm{X}+$ $99.5473 \mathrm{Y}-1472.99 \mathrm{X}^{2}-13.784 \mathrm{XY}-0.91 \mathrm{Y}^{2}$

$\mathrm{R}^{2}=97.41 \%, \mathrm{SEE}=24.51$

Where $X$ is $\mathrm{CaCl}_{2}$ concentration (\%) and $Y$ is treatment temperature $\left({ }^{\circ} \mathrm{C}\right)$

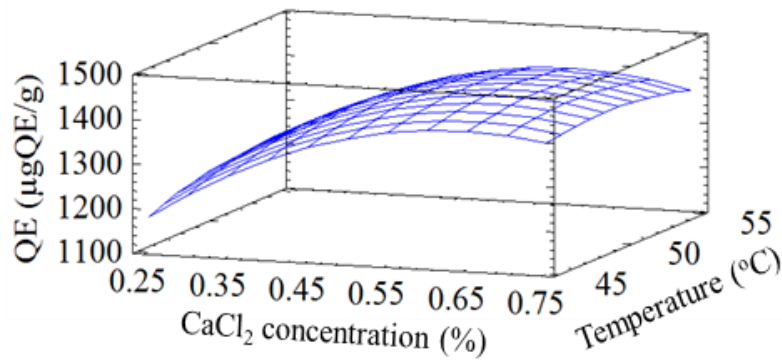

Figure 3. Influence of $\mathrm{CaCl}_{2}$ concentration and treated temperature on the $\mathrm{QE}$ of purple shallot

\subsubsection{Antioxidant activity}

The treated purple shallot at $0.25 \%$ calcium chloride had the least DPPH\% (45.36\%), whereas the treated purple shallot at $0.50 \%$ calcium chloride had the highest DPPH\% (51.63\%). However, the antioxidant activity between the sample treated in $0.5 \%$ and $0.75 \%$ calcium chloride did not show a significant difference. As shown in Figure 4, the temperature has an insignificant effect on the mean of $\mathrm{DPPH} \%$ in the purple shallot treated at the same concentration of calcium chloride (49.07-50.17\%). The beneficial effects of polyphenols have been ascribed to their strong antioxidant activity that is, their ability to scavenge oxygen radicals and other reactive species (Vijayalaxmi et al., 2015). Many polyphenolic compounds have been found to have a much stronger antioxidant activity than vitamins $\mathrm{C}$ and $\mathrm{E}$ and $\beta$ carotene within the same food (Chu et al., 2002). TPC is responsible for expressing antioxidant activity (Balik et al., 2008). In this study, a decrease in polyphenol content reflected a decrease in antioxidant capacity of purple shallot.

The quadratic models for the DPPH\% and FRAP of different treatment conditions are presented in equation 6 . The higher $\mathrm{R}^{2}$ values of these models indicated a good fit of the data.

$\mathrm{DPPH} \%=-76.66+86.76 \mathrm{X}+4.14 \mathrm{Y}-50.37 \mathrm{X}^{2}-$

$0.48 \mathrm{XY}-0.04 \mathrm{Y}^{2}$

$\mathrm{R}^{2}=84.58 \%$, $\mathrm{SEE}=2.23$

Where $\mathrm{X}$ is calcium chloride concentration (\%) and $\mathrm{Y}$ is treatment temperature $\left({ }^{\circ} \mathrm{C}\right)$



Figure 4. Influence of $\mathrm{CaCl}_{2}$ concentration and treatment temperature on the DPPH $\%$ of treated purple shallot

With these responses chosen, the overlay plot also showed the combination of the factors at which that optimum is achieved (Figure 5). The results showed that the combination of factor levels (calcium chloride concentration and treatment temperature) were $0.64 \%$ and $\approx 50^{\circ} \mathrm{C}$, respectively, which maximize the desirability of all parameters. The optimum value of hardness, TPC, TFC, QE and DPPH\% were 1288.55 (g-force), $14.02 \mathrm{mg}$ $\mathrm{GAE} / \mathrm{g}, 6.38 \mathrm{mg} \mathrm{QE} / \mathrm{g}, 1432.08 \mu \mathrm{g} \mathrm{QE} / \mathrm{g}$ and 53.05\%, respectively at these conditions.

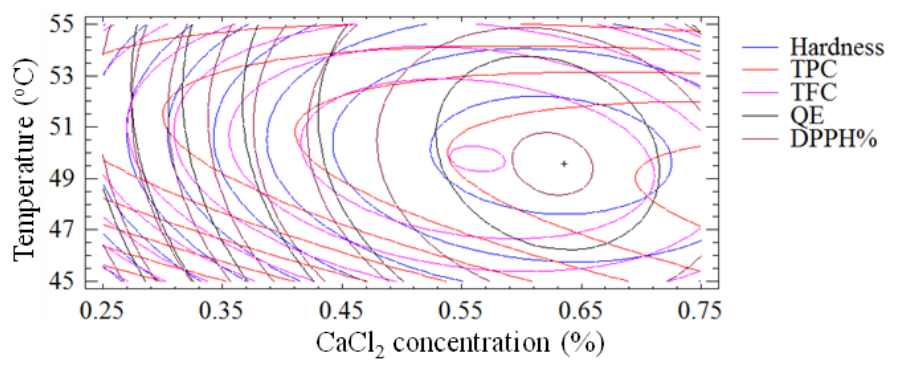

Figure 5. Overplay plot for optimal conditions

\section{Conclusion}

The application of $\mathrm{CaCl}_{2}$ significantly effects on the texture. The quality characteristics such as TPC, TFC and antioxidant potential in shallot was higher if treated with a concentration of $\mathrm{CaCl}_{2} 0.64 \%$ and heat at mild temperatures $\left(\approx 50^{\circ} \mathrm{C}\right)$. This is the first effort to study the effect of pretreatment conditions on the nutritional quality of purple shallots growing at Soc Trang, Vietnam. The combination of calcium chloride-mild temperature water treatment is being reported as a means of improving the quality, in term of texture and bioactive compounds, the antioxidant activity of purple shallot growing in Soc Trang, Vietnam. In addition, the higher quality pretreated sample will be a better source and effectively used for further processing of new products from purple shallot growing in Vietnam. 


\section{References}

Alzamora, S. M., Salvatori, D., Tapia, M.S., LópezMalo, A., Welti-Chanes, J. and Fito, P. (2005). Novel functional foods from vegetable matrices impregnated with biologically active compounds. Journal of Food Engineering, 67(1-2), 205-214. https://doi.org/10.1016/j.jfoodeng.2004.05.067

Aoyama, S. and Yamamoto, Y. (2007). Antioxidant activity and flavonoid content of Welsh onion (Allium fistulosum) and the effect of thermal treatment. Food Science and Technology Research, 13(1), 67-72. https://doi.org/10.3136/fstr.13.67

Artes, F., Conesa, M.A., Hernandez, S. and Gil, M.I. (1999). Keeping quality of fresh-cut tomato. Postharvest Biology and Technology, 17(3), 153162. https://doi.org/10.1016/S0925-5214(99)00044-7

Balik, J., Kyselakova, M., Vrchotová, N., Tř́íska, J., Kumšta, M., Veverka, J., Hic, P., Totušek, J. and Lefnerová, D. (2009). Relations between polyphenols content and antioxidant activity in vine grapes and leaves. Czech Journal of Food Sciences, 26(Special Issue), S25-S32. https:// doi.org/10.17221/246/2008-CJFS

Carrea, G., Bovara, R., Pasta, P. and Cremonesi, P. (1982). The effect of Hofmeister anions and protein concentration on the activity and stability of some immobilized NAD-dependent dehydrogenases. Biotechnology and Bioengineering, 24(1), 1-7. https://doi.org/10.1002/bit.260240102

Castaldo, D., Villari, G., Laratta, B., Impembo, M., Giovane, A., Fasanaro, G. and Servillo, L. (1996). Preparation of high-consistency diced tomatoes by immersion in calcifying solutions. A pilot plant study. Journal of Agricultural and Food Chemistry, 44(9), 2600-2607. https://doi.org/10.1021/jf9602030

Chang, C.C., Yang, M.H., Wen, H.M. and Chern, J.C. (2002). Estimation of total flavonoid content in propolis by two complementary colourimetric methods. Journal of Food and Drug Analysis, 10(3), 178-182.

Chu, Y.F., Sun, J.I.E., Wu, X. and Liu, R.H. (2002). Antioxidant and antiproliferative activities of common vegetables. Journal of Agricultural and Food Chemistry, 50(23), 6910-6916. https:// doi.org/10.1021/jf020665f

Dong, X., Wrolstad, R.E. and Sugar, D. (2000). Extending the shelf life of fresh-cut pears. Journal of Food Science, 65(1), 181-186. https:// doi.org/10.1111/j.1365-2621.2000.tb15976.x

Fallik, E. (2004). Prestorage hot water treatments (immersion, rinsing and brushing). Postharvest Biology and Technology, 32(2), 125-134. https:// doi.org/10.1016/j.postharvbio.2003.10.005

Farsi, M.A. and Lee, C.Y. (2008). Nutritional and functional properties of dates: a review. Critical Reviews in Food Science and Nutrition, 48(10), 877887. https://doi.org/10.1080/10408390701724264

Gómez-López, V.M. (Ed.). (2012). Decontamination of fresh and minimally processed produce. United Kingdom: John Wiley and Sons. https:// doi.org/10.1002/9781118229187

Gorinstein, S., Jastrzebski, Z., Leontowicz, H., Leontowicz, M., Namiesnik, J., Najman, K. and Bae, J.H. (2009). Comparative control of the bioactivity of some frequently consumed vegetables subjected to different processing conditions. Food Control, 20 (4), 407-413. https://doi.org/10.1016/ j.foodcont.2008.07.008

Gupta, S., Cox, S. and Abu-Ghannam, N. (2011). Effect of different drying temperatures on the moisture and phytochemical constituents of edible Irish brown seaweed. LWT-Food Science and Technology, 44(5), 1266-1272. https://doi.org/10.1016/j.lwt.2010.12.022

Hashmi, M.A., Khan, A., Hanif, H., Farooq, U. and Perveen, S. (2015). Traditional Uses, Phytochemistry, and Pharmacology of Olea europeae (Olive) Evidence-Based Complementary Alternative Medicine, 2015, 541591. https:// doi.org/10.1155/2015/541591

Ihl, M., Aravena, L., Scheuermann, E., Uquiche, E. and Bifani, V. (2003). Effect of immersion solutions on shelf-life of minimally processed lettuce. LWT-Food Science and Technology, 36(6), 591-599. https:// doi.org/10.1016/S0023-6438(03)00065-3

Kosar, M., Bozan, B., Temelli, F. and Baser, K.H.C. (2007). Antioxidant activity and phenolic composition of sumac (Rhus coriaria L.) extracts. Food Chemistry, 103(3), 952-959. https:// doi.org/10.1016/j.foodchem.2006.09.049

Lamikanra, O. (2002). Fresh-cut fruits and vegetables: science, technology, and market. USA: CRC Press. https://doi.org/10.1201/9781420031874

Lara, I., Garcia, P. and Vendrell, M. (2004). Modifications in cell wall composition after cold storage of calcium-treated strawberry (Fragaria $\times$ ananassa Duch.) fruit. Postharvest Biology and Technology, 34(3), 331-339. https://doi.org/10.1016/ j.postharvbio.2004.05.018

Liyana, P.C.M. and Shahidi, F. (2005). Antioxidant activity of commercial soft and hard wheat (Triticum aestivum L.) as affected by gastric $\mathrm{pH}$ conditions. Journal of Agricultural and Food Chemistry, 53(7), 2433-2440. https://doi.org/10.1021/jf049320i

Loaiza-Velarde, J.G., Tomás-Barberá, F.A. and Saltveit, 
M.E. (1997). Effect of intensity and duration of heatshock treatments on wound-induced phenolic metabolism in iceberg lettuce. Journal of the American Society for Horticultural Science, 122(6), 873-877. https://doi.org/10.21273/JASHS.122.6.873

Lum, M.S. and Norazira, M.A. (2011) Effects of Hot Water, Submergence Time and Storage Duration on Quality of Dragon Fruit (Hylocereus polyrhizus). Journal of Agricultural Science, 3, 58-63. https:// doi.org/10.5539/jas.v3n1p146

Luna-Guzmán, I. and Barrett, D.M. (2000). Comparison of calcium chloride and calcium lactate effectiveness in maintaining shelf stability and quality of fresh-cut cantaloupes. Postharvest Biology and Technology, 19(1), 61-72. https://doi.org/10.1016/S0925-5214 (00)00079-X

Luna-Guzmán, I., Cantwell, M. and Barrett, D.M. (1999). Fresh-cut cantaloupe: effects of $\mathrm{CaCl}_{2}$ dips and heat treatments on firmness and metabolic activity. Postharvest Biology and Technology, 17(3), 201-213. https://doi.org/10.1016/S0925-5214(99) 00048-4

Manganaris, G.A., Vasilakakis, M., Diamantidis, G. and Mignani, I. (2007). The effect of postharvest calcium application on tissue calcium concentration, quality attributes, the incidence of flesh browning and cell wall physicochemical aspects of peach fruits. Food Chemistry, 100(4), 1385-1392. https:// doi.org/10.1016/j.foodchem.2005.11.036

Pereyra, L., Roura, S. I. and Del Valle, C.E. (2005). Phenylalanine ammonia-lyase activity in minimally processed Romaine lettuce. LWT-Food Science and Technology, 38(1), 67-72. https://doi.org/10.1016/ j.lwt.2004.05.004

Rosen, J.C. and Kader, A.A. (1989). Postharvest physiology and quality maintenance of sliced pear and strawberry fruits. Journal of Food Science, 54 (3), 656-659. https://doi.org/10.1111/j.13652621.1989.tb04675.x

Sila, D.N., Van Buggenhout, S., Duvetter, T., Fraeye, I., De Roeck, A., Van Loey, A. and Hendrickx, M. (2009). Pectins in processed fruits and vegetables: Part II-Structure-function relationships. Comprehensive Reviews in Food Science and Food Safety, 8(2), 86-104. https://doi.org/10.1111/j.15414337.2009.00071.x

Suutarinen, J., Honkapää, K., Autio, K. and Mokkila, M. (2000). The effect of $\mathrm{CaCl}_{2}$ and PME pre-freezing treatment in a vacuum on the structure of strawberries. ISHS Acta Horticulturae, 567, 783-786. https://doi.org/10.17660/ActaHortic.2002.567.173

Tunde-Akintunde, T.Y. (2010). Effect of pretreatment on drying time and quality of chilli pepper. Journal of Food Processing and Preservation, 34(4), 595-608. https://doi.org/10.1111/j.1745-4549.2008.00360.x

Thuy, N.M. and Tuyen, N.T.M. (2016). Postharvest Technology (Preservation and Processing) of agricultural products in Mekong delta. Vietnam: Can Tho University Publishing House.

Thuy, N.M., Nhu, N.T.T., Tri, N.M., Dinh, D.C., Cuong, N.P., Huong, H.T. and Tuyen, N.T.M. (2013). Effect of Pretreatments on Quality Attributes of Dehydrated Pineapple Slices. Can Tho University Journal of Science, 29, 16-24

Thuy, N.M., Tuyen, N.T.M, Cuong, N.P., Huyen, L.T.N, Phuong, N.P, Nguyen, L.T.T, Kim, J.H., Thu, N.T. and Tai, N.V. (2020). Identification and extraction method of quercetin from flesh and skin of shallot (Allium ascalonicum) cultivated in Soc Trang province, Vietnam. Food Research, (4)2, 358-365. https://doi.org/10.26656/fr.2017.4(2).306

Vega-Gálvez, A., Lara, E., Flores, V., Di Scala, K. and Lemus-Mondaca, R. (2012). Effect of selected pretreatments on the convective drying process of blueberries (var. O'Neil). Food and Bioprocess Technology, 5(7), 2797-2804. https:// doi.org/10.1007/s11947-011-0656-X

Vicente, A.R., Manganaris, G.A., Sozzi, G.O. and Crisosto, C.H. (2009). Nutritional quality of fruits and vegetables. In Florkowski, W.J., Shewfelt, R.L., Brueckner, B. and Prussia, S.E. (Eds.). Postharvest Handling: A Systems Approach, p. 57-106. USA: Academic Press. https://doi.org/10.1016/B978-0-12374112-7.00005-6

Vijayalaxmi, S., Jayalakshmi, S.K. and Sreeramulu, K. (2015). Polyphenols from different agricultural residues: extraction, identification and their antioxidant properties. Journal of Food Science and Technology, 52(5), 2761-2769. https:// doi.org/10.1007/s13197-014-1295-9

Voragen, A.G., Coenen, G.J., Verhoef, R.P. and Schols, H.A. (2009). Pectin, a versatile polysaccharide present in plant cell walls. Structural Chemistry, 20 (2), 263. https://doi.org/10.1007/s11224-009-9442-z

Wolfe, K., Wu, X. and Liu, R.H. (2003). Antioxidant activity of apple peels. Journal of Agricultural and Food Chemistry, 51(3), 609-614. https:// doi.org/10.1021/jf020782a 